UDC 342.827.2

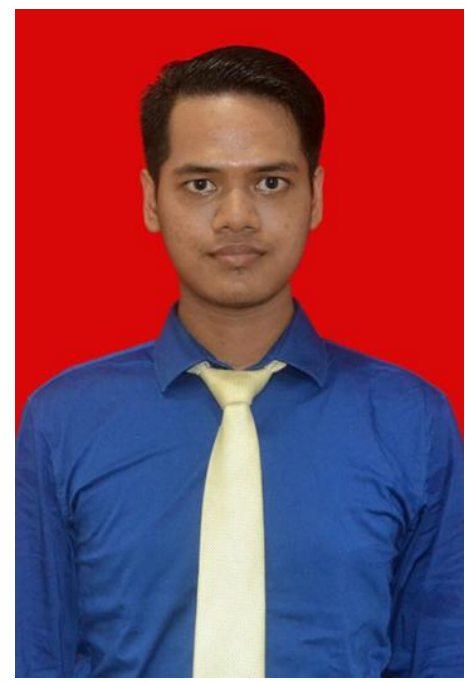

\title{
THE INTERPRETATION OF SPECIFICITY TO VOTING THROUGH REPRESENTATIVE SYSTEM IN THE GENERAL ELECTION OF THE HEAD OF REGION IN INDONESIA
}

\author{
Zulfikar Ardiwardana Wanda \\ Master degree in law, a lecturer in Faculty of Law, \\ University of Muhammadiyah Gresik, \\ Randuagung, Gresik 61121, Indonesia, East Java \\ e-mail:zulfikar9040@gmail.com
}

The journal purposes to examine The Interpretation of Specificity to Voting through Representative System in the General Election of the Head of Region. This study is a legal study conducted through library research, using conceptual and statute approach. The results of the study indicate that the collection conducted through the system of representation in the general election or the general election of the head of region based on customary law or customs and mutual agreement in Yahukimo Regency (Papua Province) and Bali Province is constitutional. With respect to voters exercising their voting right more than once or election represented in a vote based on mutual consent or agreement is constitutional and lawful given that the system or model of election has become a habit and there is Number element of compulsion from the Balinese people applied in The General Election or The General Election of The Head of Region. The General Election of The Head of Region conducted in the Province of Bali in which there are elections represented then it is permissible and legitimate and Numbert contrary to the constitution in accordance with the phrase of legal considerations from decision of the Constitutional Court which states against such things, because it is a habit And has been accepted by each party, as evidenced by the absence of objection from the voting place from each candidate pair. Based on the provision of Article 22E Paragraph (1) of the Implementation of General Election, including The General Election of The Head of Region after entering The General Election regime based on Law Number 22 of 2007 on the Organizer of The General Election and Law Number 122008 on Regional Government is implemented in a direct, public, free, secret, honest and fair every five years.

Keywords: Voting Place; Representative System; Constitutional Interpretation.

Introduction. Democracy is the political choice of the form of government adopted by the majority of countries in the world as a form of the modern state, including Indonesia since the proclamation of independence on August 17, 1945. The fourth principle of Pancasila, «Democracy led by the wisdom of wisdom in representative deliberations» became the basis of recognition of sovereignty the people embodied in the basic principles and mechanisms of democracy. Democracy in practice is more acceptable than any other political system because in the 
conception of democracy there is self-government. In that context, the principles of democracy are manifested through various forms of popular participation, one of which is then actualized in the implementation of The General Election.

Indonesia has experienced a fundamental shift in the political and administrative system in the post-reform era since 1998 and one of the proofs of its birth is marked by constitutional amendment. Constitutional reform has given birth to a state with a much more democratic regulatory arrangement where the active participation of the people is a must or "conditio sine qua Numbern" from constitutional amendments scheduled up to four (4) times. Constitutional reform has implications for democratic life in local governance system by providing capacity for political decentralization process at local government level, in particular the implementation of general election of regional head and vice regional head (The General Election of The Head of Region).

The General Election of The Head of Region is one manifestation of the actualization of the people's sovereignty in the concept of a democratic state that implies the participation of the community to directly elect their regional leaders. The General Election of The Head of Region is also considered able to accommodate a complementary integrated selection system to produce qualified candidates for elected regional heads ranging from the selection of state system, political party, administrative, until political selection. On that basis, The General Election of The Head of Region is expected to produce an aspiration, qualified and legitimate leader figure that will bring the government closer to the people. In this case, T.A Legowo stated that The General Election of The Head of Region is an integral part of the acceleration of democratization at the national level where democracy at national level will grow steadily if on the local level the values of democracy have been firmly rooted first.

When it alludes to The General Election of The Head of Region as a direct election mechanism following the shift of regional head elections to become part of the electoral regime, it is inevitable to further elaborate the significance of the values and principles of democracy. Both have close relationships that can Numbert be 
separated like two sides in a single coin. According to Arbi Sanit in his book entitled «Electoral System and Political Representation», elections are institutions that embody the principles of democracy. This is in line with Alan R. Ball's opinion that elections and democracy are closely related to substance and function because elections are the actual realization of democracy in contemporary state practice as being the primary means for the people embodied in the process of engaging the people to determine who has the legitimacy of running the wheel the power of state government.

The main principles in the implementation of democratic government are formulated in the 1945 Constitution of the State of the Republic of Indonesia (the 1945 Constitution of the Republic of Indonesia) which affirms the state of Indonesia as a democracy and a state of law. This is affirmed in the provision of Article 1 Paragraph (2) of the 1945 Constitution which stipulates that «Sovereignty is in The Hands of The People and Carried Out According to the Constitution» and paragraph (3) which reads «The State of Indonesia is A State of law». Based on the provisions of Article 1 paragraphs (2) and (3) above, the implementation of the people's sovereignty, especially in relation to The General Election of The Head of Region of The Head of Region and General Election, shall be conducted in accordance with constitutional procedures established in the constitution and prevailing laws and regulations. In the implementation of the people's sovereignty must be balanced with the principle of state law.

In relation to the implementation of the Election of regional head, the provisions in the 1945 Constitution Article 18 paragraph (4) affirm that: «Government, Regents and Mayors respectively as heads of provincial, district and municipal governments are elected democratically». The phrase «democratic» in the provisions of Article 18 paragraph (4) above is translated by the legislator (President and Parliament) through Law Number. 22 of 1999 on Regional Government with indirect selection mechanism, which is elected by Regional People's Representative Assembly. However, when the enactment of Law Number. 32 of 2004 on Regional Government, the filling and election of regional heads are Number longer elected by 
the Regional People's Representative Assembly but elected directly by the people who later reinforced in Law Number. 12 of 2008 on the Second Amendment to Law Number. 32 of 2004 on Regional Government.

In its development, after the enactment of Law Number 22 of 2007 on The Organizer of General Election, Election of regional head also experienced a regime shift previously categorized part of the regime of local government shifted to the regime election domain so that the mention of it was changed from the beginning Election of regional head into The General Election of The Head of Region. It also carries the juridical implications of absolute competence in adjudicating disputes over the results of The General Election of The Head of Region based on Law Number. 12 of 2008 on Regional Government have transferred the authority from the Supreme Court to the Constitutional Court.

The portrait of The General Election of The Head of Region travel that took place since 2005, in its implementation was Number fully democratic and constitutional. Various forms of violations are still widely practiced, whether administrative, criminal, ethical, or related to the results of The General Election of The Head of Region which are the source of horizontal disputes and conflicts. Although the rules are already exist, but irregularities and violations of these rules continue to occur, even to the end of the lawsuit to the Constitutional Court.

Since the authority to decide the dispute over the results of The General Election of The Head of Region has been transferred to the Constitutional Court, many monumental decisions have been decided by the Constitutional Court. Through the legal product of its decision, the Constitutional Court has made legal breakthroughs in which one of its decisions, namely Dispute Result of East Java Province Election in 2008 which is seen as controversial as well as monumental ruling when it becomes "stare Decision" or "Landmark Decision" in decision of The General Election of The Head of Region afterwards. In this case, the Constitutional Court is not merely a 'Court of Calculation' but the Court guarding the pillars of democracy and upholding substantive justice for not only adjudicating the dispute over the results in the calculation of the numbers but also adjudicating and at the 
same time breaking the offense occurs related to the process if there are violations that are structured, systematic, and massive.

In addition to the offenses mentioned above, there are also violations which in the process castrate the Election Principles contained in the Constitution and the prevailing laws and regulations. This can be traced to the provisions of Article 22E Paragraph (1) of the 1945 Constitution of the Republic of Indonesia which stipulates that «General elections shall be held in a direct, public, free, secret, honest and fair manner every five years». In line with Article 22E Paragraph (1) of the 1945 Constitution of the Republic of Indonesia, Article 2 of Law Number. 8 of 2012 on General Election of Members of the People's Legislative Assembly, the Regional Representatives Council, and the Regional People's Representative Assembly) also stipulates that «Elections are conducted effectively and efficiently on the basis of direct, public, free, confidential, honest and fair principles». While in the provisions of Article 56 paragraph (1) of Law Number. 32 of 2004 on Regional Government affirms that «the regional head and deputy regional head are elected in a single candidate pairs that are carried out democratically based on the direct, public, free, secret, honest and fair principle».

In this case, related to Dispute of Results of Election of Bali Province in 2013 between pair Anak Agung Gede Ngurah Puspayoga and Dewa Nyoman Sukrawan which carried by The Indonesian Democratic Party of Struggle (PDIP) and majority of political party in parliament as Petitioner with partner Made Mangku Pastika and I Ketut Sudikerta carried by LDemocratic Party (PD) as the Related Parties, the Constitutional Court through its decision Number. 62/PHPU.D-XI/2013 allows voters to exercise their voting right more than once or represented. The judgment is deemed to have violated one of the principles of the General Election, namely the one man one vote stipulated in the constitution and the positive law below which mandates that The General Election of The Head of Region must be conducted in a direct, public, free and secret manner so that voting by mechanism or system of representation is clearly contrary to the principle of direct and secret.

Related to that, I Gusti Putu Artha said that the voting system through a voting 
system or voters who exercised their voting right more than once did not only happen in the Regional Head Election of Bali Province, but it has been applied in several General Election and The General Election of The Head of Region in Papua Province not as the Noken system. The model of Noken election is interpreted as a system in which the voting stage of the voters of the community members in exercising their right to vote is represented by the chief of the tribe and inserting into the bag (sack) which is the inheritance of ancestral heritage in the form of bag (sack) made of woven bark as typical handicrafts people of Papua.

The Noken system as a mechanism for selecting customary representatives has been implemented in Yahukimo District (Papua Province) in every election and election. For the Yahukimo community, Noken is not only useful for carrying crops and as a cultural symbol, but also used as a place to put ballots that have been cast or ticked, both in the implementation of elections and The General Election of The Head of Region. The selection of this Noken model has also been acknowledged by its legal legitimacy because it obtains the recognition of constitutionality through the Decision of the Constitutional Court Number 47-81/PHPU.A-VII/2009. Based on the track record of electoral implementation in Papua Province, it can be said that the use of Noken as a substitute for the ballot box itself has been going on since the first election was held in Papua in 1971.

Still according to I Gusti Putu Artha, yoting in The General Election of The Head of Region in Bali Province is Numbert familiar with the Noken system which is the system of customary election in Papua. Similarly, Hasyim Asy'ari said the implementation of democracy in certain contexts can be represented as using the Noken system in Papua.

For this reason the topic of interpretation of the specificity of voting through the representation system in the election is worthy to be reviewed. The study focused on the issue of 1). How is the Decision of legal consideration of the Constitutional Court against Election Principles through the System of Representation in Voting? 2). How is the enforcement of the Constitutional Court's Decision on the Interpretation of the Constitutionality of Election Principles in the Voting? 
This study is a normative law study conducted through literature study or library research, using conceptual approach, statute approach, and case approach. The legal materials used are primary, tertiary, and secondary legal materials.

\section{DISCUSSION.}

A. Legal Consideration Decision of the Constitutional Court on Election Principles Through Representative System in Voting

On June 30, 2013 the Constitutional Court has adjudicated the case Number. 62 /PHPU.D-XI/2013 concerning Disputes on the Results of the Bali Province Election. The ruling begins on the petition filed by Anak Agung Gede Ngurah Puspayoga and Dewa Nyoman Sukrawan (Puspayoga-Sukrawan) as the Petitioner against the Decree of the Provincial Election Commission Number 287/Kpts /KPUProv-016/2013 as the Respondent who won Made Mangku Pastika and Ketut Sudikerta (Pasti-Kerta) as the Related Party.

On 26 May 2013, the Bali Provincial Election Commission has conducted the Recapitulation of Vote Count Result of the Government and Vice Government Election of Bali Province according to the Minutes of the Provincial Election Number. 494/BA/V/2013 dated 26 May 2013, the results in detail are as follows:

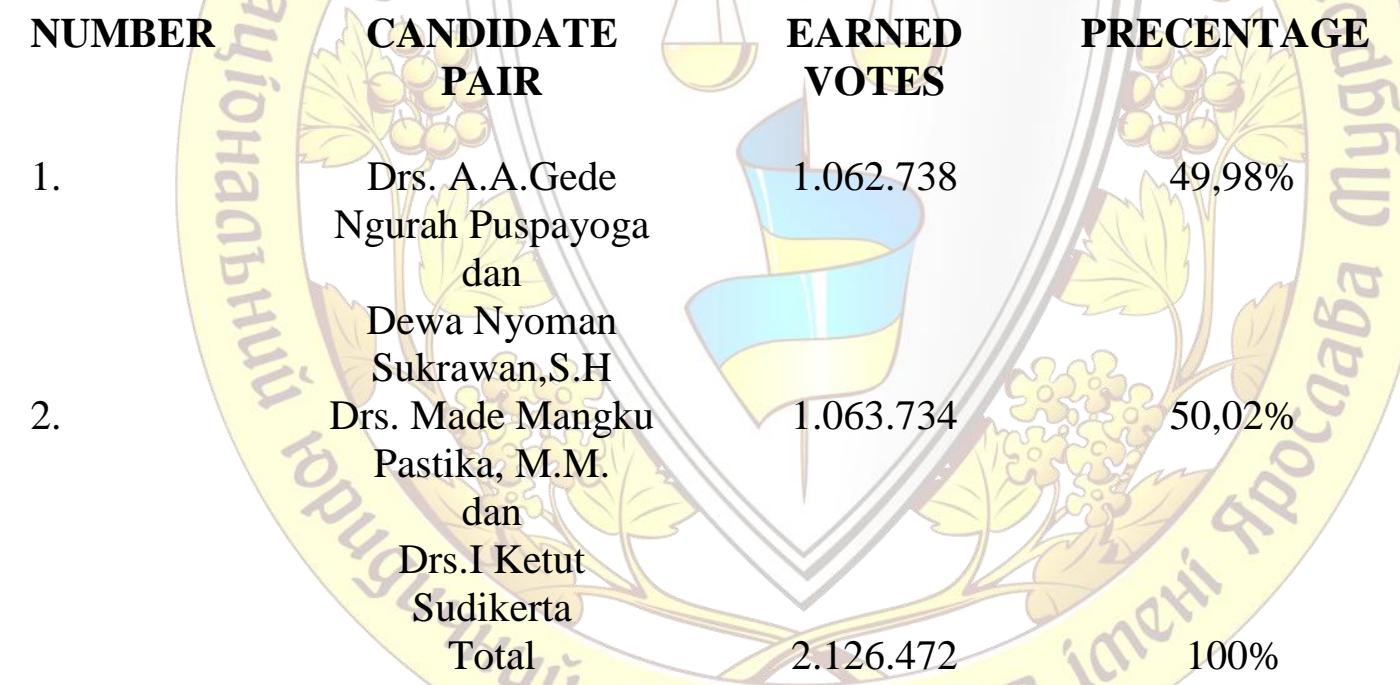

Source: Constitutional Court Decision Number 62 / PHPU.D-XI / 2013.

The result of vote count conducted by Bali Provincial Election Commission as the Respondent is suspected to result from election process which is contradictory to the principles of the election, which is direct and confidential in addition to the number of violations that occurred in the stages of the Election of Bali Province that significantly affect the acquisition of the votes of both candidate pairs Head of region and deputy head of region. In relation to the violations occurring as mentioned above is a logical consequence of the application of the principle of democracy with all its advantages and disadvantages. 
Voters exercised more than one vote at the same voting place or different voting place or voters represented; (2) The Election Commission of Bali Provincial shall not open the ballot boxes and/or voting files; (3) Systematic, structured, and massive violations include money politics, intimidation, mobilization of civil servants, and directing voters to vote for Candidate Pair Number 2 (Related Party) in Bali Election Province.

The representative system applied in The General Election of The Head of Region Bali Province is commonly referred to as the bonding system. The bonding system is a system whereby a person may represent his/her right to vote to a person who is entrusted to exercise his/her right to vote in a particular candidate based on his or her consent which is already a Balinese culture in The General Election of The Head of Region. The bonding system has similarities and differences with the prevailing Noken system in Papua. The equation lies in the procedure or mechanism of its representation in which the electorate, either the chief or the head of the family or relatives uses his or her right to vote more than once with the consent or agreement of the result of the discussion of the owner of the voting power to be represented. The difference lies in the means or tools used in voting where the bonding system still uses the ballot boxes that have been provided by the voting place, while the Noken system uses a special place in the form of bags or pockets placed on the neck.

In its development, the procedure or mechanism of the use of Noken in voting other than placed in the neck, can also be plugged or planted in the voting place area with The Group of Voting Organizer. This provision was only established after the Constitutional Court Decision Number 47-81/PHPU.A-VII/ 2009 which legalized the use of the Noken system in the Election The General Election of The Head of Region in Yahukimo Regency as well as being a jurisprudence for the apparatus of use for the relevant government apparatus as well as the rural areas of Papua. The new provisions concerning the mechanics of the use of Noken are regulated in Article 3 paragraph 1 of the Decision of the Papua Election Commission Number 01/Kpts/KPU.Prov.03/2013 on Technical Guidelines for Procedures for Voting Using Noken as a Replacement to a Voice Box stating: 
(1) Groups and/or members of the voting community using Noken may provide a stick planted in the voting place area with instructions from the Chairperson of the group of voting organizer which functions to tie the Noken to the pole during the voting or in other ways according to local custom such as hanging Noken necked (bolded by Author).

The decision of the Constitutional Court to legalize or give legal legitimacy to the customary Noken system by the community in Yahukimo Regency has also inspired the Constitutional Court to pass a similar ruling on the dispute over the results of the Bali Provincial Election in 2013. The Constitutional Court legalized the vote through the upper tie representative system agreements or agreements as well as because it is a custom which has previously been done in previous elections as applied in Yahukimo. The legitimacy of the law is set forth in the Constitutional Court Decision Number 62/PHPU.D-XII/2013 concerning Dispute on Election Result of Bali Province Election. In the consideration of the legal consideration of the Constitutional Court in its decision states that:

To such matters, as it is customary and has been accepted by each party, as evidenced by the absence of objections from the voting place witnesses of each candidate pair, as evidenced by the statements of the witnesses I Nyoman Rata, I Ketut Sudi, and I Ketut Lali, and there is Number element of coercion and/or manipulation of the voters represented (vide statement of Petitioner I Wayan Kerdung, Nengah Budi, I Wayan Suparta, I Ketut Sudarma, I Wayan Suliadi, I Komang Mudana, I Ketut Sudi, I Nengah Gatip, I Wayan Pikun, I Ketut Lali, I Nyoman Mudana, I Ketut Suitra); and both candidates are equally benefited and / or harmed (vide statement of Petitioner I Nyoman Mudana); then based on the principle of benefit, the Court is of the opinion that the a quo election is acceptable (bold by the Author).

From the legal considerations above, there are 2 (two) points underlying the Constitutional Court ruling on why Bali Province is allowed to use the system of binding representation in its voting violating constitutional provisions set forth in Article 22E Paragraph (1) of the 1945 Constitution of the Republic of Indonesia and the positive legal regulations set forth in Law Number 12/2008 on Regional Government and Law Number. 8 Year 2012 on General Election of Members of The House of Representatives, The Regional Representative Council, and Regional People's Representative Assembly.

First, it is customary and has been accepted by each side. This is similar to the 
Noken system in which the model of election is also a custom and even customary law applicable to the Yahukimo and inland communities of Papua because it is feared that conflict will arise among local community groups if forced to use a voting model in accordance with the constitution and positive law. After the decision of the Constitutional Court, one of the principles of national constitutionality of the General Election, namely one man one vote, does Numbert apply to the people of Bali and Yahukimo and the rural communities of Papua.

Second, the a quo election is acceptable. In this case the Constitutional Court can understand and appreciate the value of local living culture and developing where the system of binding election in the voting has become a local wisdom for the community of Balinese people with consideration of the principle of expediency. The principle of legal benefit must essentially be useful for the happiness of human life.

In this case, the Constitutional Court makes a choice on the theory of legal objectives which focuses on the principle of benefit as the legal consideration which is formulated in solving the dualism of electoral principles between the electoral principles stipulated in the national law of one man one vote and the principle of election of customary representatives as enacted in the Bali Province Election Year 2013.

The Constitutional Court ruling on the case of dispute over the results of the Bali Provincial Election based on the consideration of the agreement or agreement and habits that have been done in the previous General Election and General Election in the voting stages in which voters use their voting right more than once or voters who are represented by the election model. In its legal considerations, the Constitutional Court states:

... but according to the witnesses of the Petitioners' witness, I Nyoman Mudana, that the witness also chose more than once for the Candidate Pair Number 1 (Petitioner) to represent the witness's mother because he was ill. In addition, based on the statements of Petitioners I Nyoman Rata, I Ketut Sudi and I Ketut Lali, voters who voted more than once by representatives have been elected since the Legislative Election, Presidential Election, and Regency Election, and have never been disputed. Moreover, according to the fact of the hearing, the witnesses who received the mandate from the Petitioners signed the C1-KWK.KPU Model Form and Number one objected about the voting that voted more than once or the voters represented (bold by the Author).

Based on the phrase that the Author print thickness in the legal considerations 
of the Constitutional Court formulated above, provides an understanding that the system of representation in the voting that took place in The General Election of The Head of Region Bali Province based on two aspects as mentioned in the legal considerations above discussion, namely the aspect of « agreement or agreement «and also on the» custom «aspect.

The phrase «has been done since the Legislative Election, the Presidential Election, and The General Election of The Head of Region, and has never been questioned» implying that the system of representatives in voting in The General Election of The Head of Region has been done before the dispute over the results of The Bali Province Election in 2013 which was charged to the Constitutional Court . Since it has become a habit, the voting where voters use their voting rights more than once is Numbert questioned by the community concerned

While the phrase «to represent the witness's mother because of illness» and «Number one complains about the voting of more than one vote or the represented voters» is a form of agreement or agreement. Although in both phrases it is Numbert mentioned the existence of a word of agreement or agreement, but it can be implicitly implied that with I Nyoman Mudana (Petitioner's witness) representing his mother to cast his vote in addition to the right to vote I Nyoman Mudana own, of course can be predicted or concluded that the child has received approval or mandate from his ailing mother to represent him because he can Numbert come alone to the voting place.

Neither is the phrase «Number one raises an objection concerning the voting of more than one vote or the represented representation» constitutes a form of concession or agreement of the local community, in this case the Balinese community. Who has agreed and become a habits in the next General Election or The General Election of The Head of Region. Without the consent or collective agreement of the community concerned, the Election and The General Election of The Head of Region by using a representative system as applied in the Province of Bali shall Numbert and shall proceed as always and shall always have the potential to create continuous conflict between the participants and the organizers of The General 
Election of The Head of Region as well as the related parties as in the consideration the judgment law of the Constitutional Court further states:

Furthermore, in relation to the existence of voters who voted more than once and conducted without mutual agreement, the Court found the fact that the Respondent and Panwaslu had taken corrective action by re-voting at voting place 3 of Bungkulan Village, Sawan Sub-district, Buleleng Regency, on 22 May 2013, as in the previous voting there were voters who voted for more than 100 ballot papers for the benefit of the Serial Number 1 Candidate Pair (vide witness of the Respondent Nengah Sucita, witness of the Related Party Komang Merta Yasa and evidence of PT-15).Based on the consideration of the above legal evidence and facts, voters who choose more than once in the context of representing the family and are Numbert manipulative, according to the Court are indeed proven, but it has been done in the previous General Elections and has never been questioned so that it can be accepted. The voters who choose more than once with manipulative motivation is Numbert justified and must be processed further under the applicable laws and regulations. Therefore, the a quo Petitioners' argument is groundless according to law (bold by Author).

From the consideration of legal consideration above, the Constitutional Court further strengthens the aspect of consent or collective agreement in terms of voting through the system of representation in General Election and The General Election of The Head of Region that occurred in Bali Province. The facts revealed in the hearing that the Respondent and the Election Supervisory Committee as the organizer of The General Election of The Head of Region an initiative have taken corrective action by re-voting in some districts of the region suspected of violation in the voting. In this regard, the Constitutional Court may assess and formulate the construction of the judgment through its legal considerations derived from the facts revealed in the trial that voters who elect more than once with manipulative motivation can Numbert be justified and prosecuted in the community concerned

In this case, the connection with the Constitutional Court in its decision allows voters to vote by representing, where the basis of the constitutional judge to decide that electing the regional head by representing it is to hear the testimony of one of the witnesses of the applicant. According to the author of what has been done by the judges of the constitution mentioned above is a mistake and without a solid foundation. For as a judge in this matter the constitutional justices are Numberugh only with the testimony of one witness alone as a basis for permitting or deciding that the vote represented is legitimate. Is Numbert that one witness is Numbert or is Numbe as a witness as revealed in the principle which says "unus testis nullus testis" (one witness is Numbert a witness) but the minimum is 2 witnesses as the basis that 
the judge may believe that the election of the regional head may be done by way of representation. .

It is also important to see that the judge in deciding a case then the judge is forbidden to refuse the case on the grounds that there is Number law, Number legal basis or Number provisions governing it as stated in the principle which states the principle of "ius curia novtt" (the judge does Numbert may refuse a case by reason of Number law). In other words, the judge decides that a judge can Numbert or may Numbert decide a case if there is Number strong basis in accordance with the settled case, but must explore the law, both national law and customary law in society, so that the judge in decide the case feel confident accompanied by existing evidence.

Based on the understanding and evaluation of facts revealed in the hearing, the Constitutional Court, based on a contextual meaning approach, implies a legal decision or legal legitimacy of the validity of voting through a system of representation on the consent or common agreement and customs of the Bali provincial elections. In this case the Constitutional Court as the guardian of the formal constitution, also acts in upholding the living constitution as it applies in Yahukimo District and Bali Province in voting through a system or principle of representation where the principle overrides the principle of direct and secret (one man one vote) guaranteed in the 1945 Constitution of the Republic of Indonesia and the positive national law.

Based on the consideration of the decision of the Constitutional Court above related to the decision of The General Election of The Head of Region Bali which allows the system of representation in The General Election of The Head of Region, the writer is of the opinion that The General Election of The Head of Region conducted in Bali Province in which there is election represented then it is permissible and legitimate and Numbert contradictory to the constitution in accordance with the content of the legal consideration phrase of the Constitutional Court decision which states «Against such a matter, as it is customary and has been accepted by each party, as evidenced by the absence of objection from the polling witnesses of each candidate pairs ... «And» then by virtue of the principle of 
expediency, the Court is of the opinion that the a quo election is acceptable (permissible)».

\section{B. Enforcement of Constitutional Court Decision on Interpretation of}

\section{Constitutionality Principles of Election in Voting}

The decision of the Constitutional Court is a binding and final decision. Therefore such a decision must be based on philosophical values and have a binding legal certainty value, which is rooted in the values of justice. So the Constitutional Court's decision always upholds the values of justice and leads to justice and legal certainty; Justice becomes the main substance which ideally determines the decision of the Constitutional Court. This substantive justice contains the spirit or values of manifestation of juridical interests relating to humanity, Numbert merely the interests of formalities.

Article 24C Paragraph (1) of the 1945 Constitution determines the decision of the Constitutional Court to be final so that it is closely related to the binding legal force. This is literally a final and binding decision of the Constitutional Court having its own legal meaning. If it is related to the provisions of Article 24C paragraph (1) of the 1945 Constitution juncto Article 10 paragraph (1) of Law Number. 24 of 2003 on the Constitutional Court, the phrase «... the verdict shall be final and binding» shall Numbert be released from the phrase «The Constitutional Court has the authority to hear at the first and final level ...». If we look at it, it can be interpreted that the Constitutional Court has the authority to try cases on two levels, namely first and last level. That is, the Constitutional Court as a judicial institution has the authority to examine, hear and decide cases that are done in stages through two spaces, namely at the first level and last level.

The phrase «... the verdict is final» is an affirmation of the phrase «... last ...». While the phrase «... on the first level ...» the absence of provisions of the Constitutional Court's binding decisions. It means that the final decision of the Constitutional Court is the verdict handed down at the last level, whereas the decision of the Constitutional Court imposed on the first level of the absence of the provisions is final. On that basis, the decision of the Constitutional Court is possible to be re- 
submitted to the Constitutional Court for its constitutionality test, since in some cases the Constitutional Court's decision needs to be improved so as to avoid the form of human rights violation

The inaccuracy in interpreting the provisions on the final decision of the Constitutional Court can be seen and observed so as to result in the judgment of the Constitutional Court ruling obtaining final and binding legal power after it was pro Numberunced in the hearing and Number legal action can be taken again so that the decision of the Constitutional Court can Numbert be filed a review tested (reconstitution review). If the decision of the Constitutional Court is final and Numbert testable, then the formulation of Article 24C Paragraph (1) of the 1945 Constitution should read, «The Constitutional Court has the authority to hear and the verdict is final ...» by removing the phrase «at the first and final level» and its editors read, «The Constitutional Court has the authority to hear and its verdict is final to test ...». This is done so as Numbert to cause obscure legal $\mathrm{N}$ so far between the formulation of Article 24C paragraph (1) of the 1945 Constitution of the State of the Republic of Indonesia is different from the implementation of its law.

The authority to decide on election and election disputes conducted by the Constitutional Court is the authority relating to the constitutionality in which The General Election of The Head of Region is a democratic instrument regulated by the constitution as a «public law» so there must be a guarantee of constitutionality of the implementation of the General Election. Constitution as the highest form of social agreement concerning the public interest and protection of human rights that must be guarded by the Constitutional Court is very clear is a public law.

Related to that matter, it is interesting to observe that in the case of dispute of The General Election of The Head of Region of Yahukimo Regency and Bali Province has conducted voting stages with election representation system that clearly deviates from the provisions of the 1945 Constitution of the Republic of Indonesia and the prevailing positive law contained in the provisions of the Regional Government Law on legislative election, and the Presidential Election Law. Explicitly stated in Article 22E of the 1945 Constitution of the Republic of Indonesia 
of 1945 that «General elections are held in a direct, public, free, secret, honest and fair manner every five years». In its development, The General Election of The Head of Region also included part of the election regime with the issuance of Law Number. 22 of 2007 on the Implementation of General Elections and Law Number. 12 Year 2008 on Regional Government.

Conclusion. Based on the results of the analysis, it can be concluded as follows:

1. Whereas the collection conducted through the system of representation in The General Election of The Head of Region The General Election of The Head of Region based on customary law or customs and mutual agreement in Yahukimo Regency (Papua Province) and Bali Province is constitutional. And with regard to voters exercising their voting right more than once or election represented in a vote on the basis of mutual consent or agreement is constitutional and lawful is done considering that the system or model of election has become a habit and there is Number element of compulsion from the Balinese society applied in The General Election of The Head of Region

2. Whereas the Regional Head General Election conducted in the Province of Bali in which there is an election represented then it is permissible and lawful to be conducted and Numbert contradictory to the constitution in accordance with the content of the legal consideration phrase of the Constitutional Court decree stating «Against such matter, because has been customary and has been accepted by each party, as evidenced by the absence of objections from the voting witnesses of each candidate pair.

\section{Books}

\section{Reference:}

Gaffar, Janedjri M. 2013. Demokrasi dan Pemilu di Indonesia. Jakarta: Konstitusi Press.

HarjoNumber, 2008, Konstitusi Sebagai Rumah Bangsa, Sekretariat Jenderal dan Kepaniteraan MKRI, Jakarta.

HendratNumber, Edie Toet. 2009, Negara Kesatuan, Desentralisasi, dan Federalisme,

Konstitusi, Mahkamah. 2010, Hukum Acara Mahkamah Konstitusi, Sekretariat Jenderal dan Kepaniteraan Konstitusi, Jakarta.

Latief, Abdul.2009,FungsiMahkamahKonstitusiUpayaMewujudkanNegara Hukum Demokrasi. Total Media, Jakarta.

Manan, Bagir. 1999, Perjalanan Historis Pasal 18 UUD 1945, Perumusan dan Undang- 
Undang Pelaksanaannya, Unsika, Jakarta.

MD, Moh. Mahfud. 1999. Hukum dan Pilar-Pilar Demokrasi. Yogyakarta: Gama Media.

MD, Moh. Mahfud. 1993. Demokrasi Dan Konstitusi Di Indonesia Studi Tentang

Siahaan, Maruarar. 2010, Hukum Acara Mahkamah Konstitusi Republik Indonesia (edisi 2), Sinar Grafika, Jakarta.

Syaukani AR dkk, 2009, OtoNumbermi Daerah Dalam Negara Kesatuan, Cet.7, Pustaka Pelajar, Yogyakarta.

\section{Website}

La Ode Adi Rusma, Mengembalikan Hakim Sebagai Penegak Keadilan, http://www.duniakontraktor.com/mengembalikan-hakim-sebagai-penegak-keadilan/html, diakses pada tanggal 21 April 2014.

Luki Junizar, http://www. Kontroversi Dalil Akil dalam Pilgub Bali, diakses pada tanggal 5 Januari 2014.

Mateus SuseNumber, Hak Konstitusional Masyarakat Adat, http://www.equator-news.com, diakses pada tanggal 21 Maret 2014.

Miftakhul Huda, "Mahkamah Konstitusi dan Keadilan Substantif", http://www.miftakhulhuda.com/2009/07/mk-dan-keadilan-substantif.html, diakses pada 12 April 2014.

\section{Regulation}

Undang-Undang Dasar Negara Republik Indonesia Tahun 1945.

Undang-Undang Republik Indonesia Numbermor 24 Tahun 2003 Tentang Mahkamah Konstitusi (Lembaran Negara Republik Indonesia Tahun 2003 Numbermor 98, Tambahan Lembaran Negara Republik Indonesia Numbermor 4316).

Undang-Undang Republik Indonesia Numbermor 32 Tahun 2004 Tentang Pemerintahan Daerah (Lembaran Negara Republik Indonesia Tahun 2004 Numbermor 125, Tambahan Lembaran Negara Republik Indonesia Numbermor 4437).

Undang-Undang Republik Indonesia Numbermor 12 Tahun 2008 Tentang Pemerintahan Daerah (Lembaran Negara Republik Indonesia Tahun 2008 Numbermor 59, Tambahan Lembaran Negara Republik Indonesia Numbermor 4844).

Mahkamah Konstitusi (Lembaran Negara Republik Indonesia Tahun 2011 Numbermor 70, Tambahan Lembaran Negara Republik Indonesia Numbermor 4844).

PUTUSAN MAHKAMAH KONSTITUSI REPUBLIK INDONESIA, PERKARA NUMBERMOR 62/PHPU.D-XI/2013.

Зульфикар Ардивардана Ванда. Интерпретация специфики голосования на основе пропорциональной избирательной системы во время всеобих выборов главы региона в Индонезии.

Рассмотрена специифика голосования на основе пропорииональной избирательной системы на всеобщих выборах главы региона. Результаты исследования архивных документов позволяют сделать вывод, что голосование, проведенное по этой системе, как и всеобщие выборы главы региона Яхукимо Ридженси (провинщия Папуа) и в провинции Бали, являются конституционныли. Что касается избирателей, которые активно пользуются своим правом голоса на основе взаимного согласия или согламения, также являются конституциионными и законными, учитывая, что система или модель выборов стали для них уже привычными, хотя в выборах и присутствует некоторый элемент принуждения. Общие выборы главы региона, проведенные в провинции Бали, не противоречат конституции страны и их результаты подтверждены решением Конституционного суда. На основании положений $n .1 \mathrm{~cm} .22^{E}$ «O проведении всеобщих выборов», в том числе $u$ общих выборов главы региона, выборы регионального правительства проводятся также на основе прямого и равного избирательного права при тайном голосовании каждые пять лет. 
Ключевые слова: место голосования; представительная система; конституционная интерпретация.

Зульфікар Ардівардана Ванда. Інтерпретація специфіки голосування на основі пропорційної виборчої системи під час загальних виборів глави регіону в Індонезії.

Розглянуто спеичифіку голосування на основі пропориійної виборчої системи на загальних виборах глави регіону. Результати дослідження архівних документів дозволяють дійти висновку, щзо голосування, проведене за иією системою, як $і$ загальні вибори глави регіону в Яхукімо Рідженсі (провінція Папуа) і в провінції Балі, є конституційними. Що стосується вибориів, які активно користуються своїм правом голосу на основі взаємної згоди або угоди, також є конституціийними $і$ законними, з огляду на те, щзо система або модель виборів стали для них уже звичними, хоча у виборах ще присутній певний елемент примусу. Загальні вибори глави регіону, проведені в провінщії Балі, не суперечать конституції країни $i$ їх результати підтверджені ріменням Конституційного суду. На підставі положень $n .1 \mathrm{~cm} .22^{E}$ «Про проведення загальних виборів», в тому числі $i$ загальних виборів глави регіону, вибори регіонального уряду проводяться також на основі прямого і рівного виборчого права при таємному голосуванні кожні п'ять років.

Ключові слова: місце голосування; представницька система; конституційна інтерпретація.

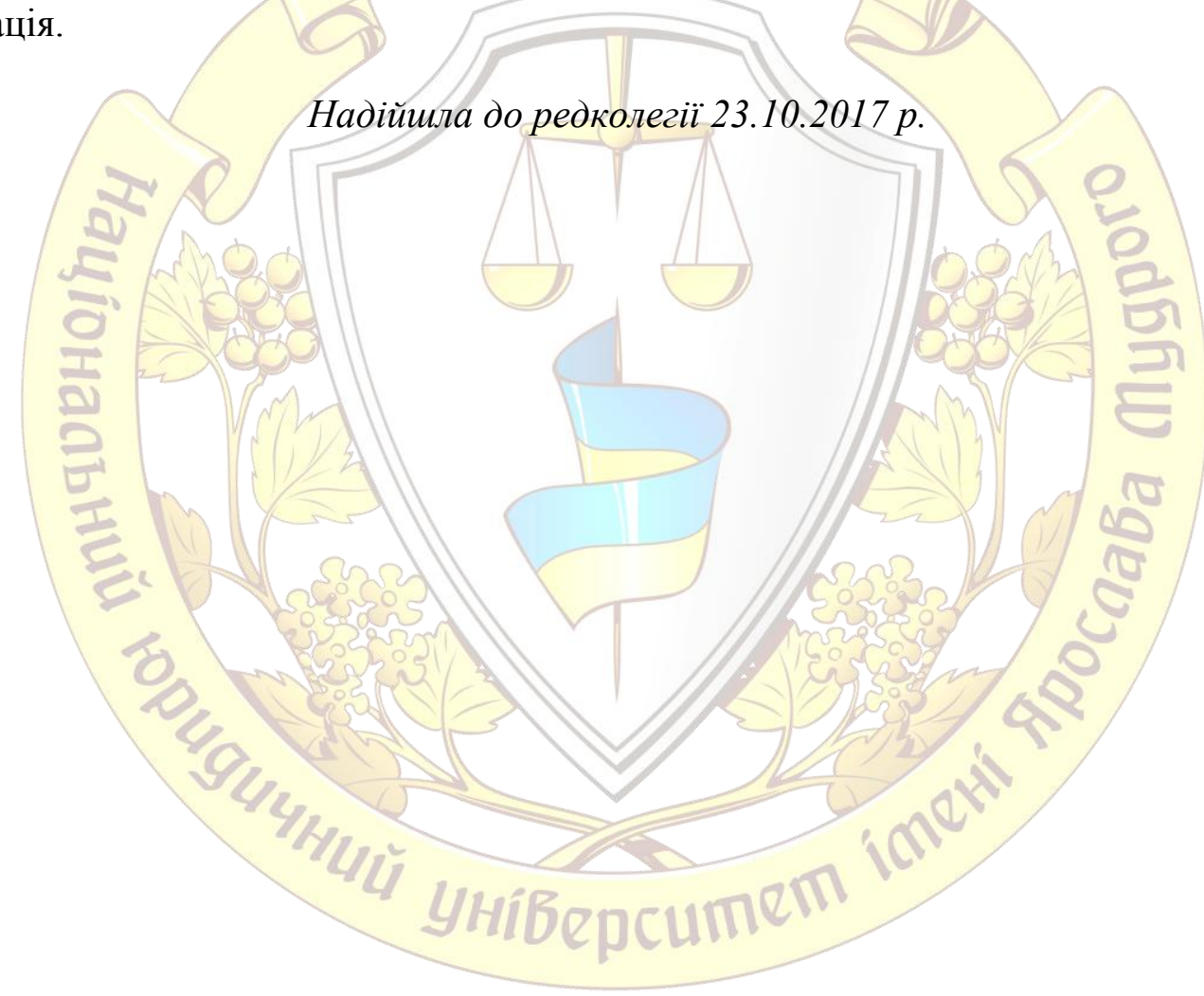

